\title{
LA-UR- $99-823$
}

Title:

REMOTE MONITORING OF VOLCANIC GASES USING PASSIVE

FOURIER TRANSFORM SPECIROSCOPY

$$
\text { CONF- } 990616-
$$

\section{Submitted to:}

Steven P. Love, NIS-2

RECEIVED

MAY O 31999

Author(s):

Fraser Goff, EES-1

OSTI

Dale Counce, EES-1

Stephen C. Schmidt, NIS-2

Claus Siebe, Instituto de Geofisica, Universidad Nacional Autonoma de Mexico

Hugo Delgado, Instituto de Geofisica, Universidad Nacional Autonoma de Mexico

OSA Topical Conference

Santa Barbara, CA

Jume 21-25, 1999

MASTER
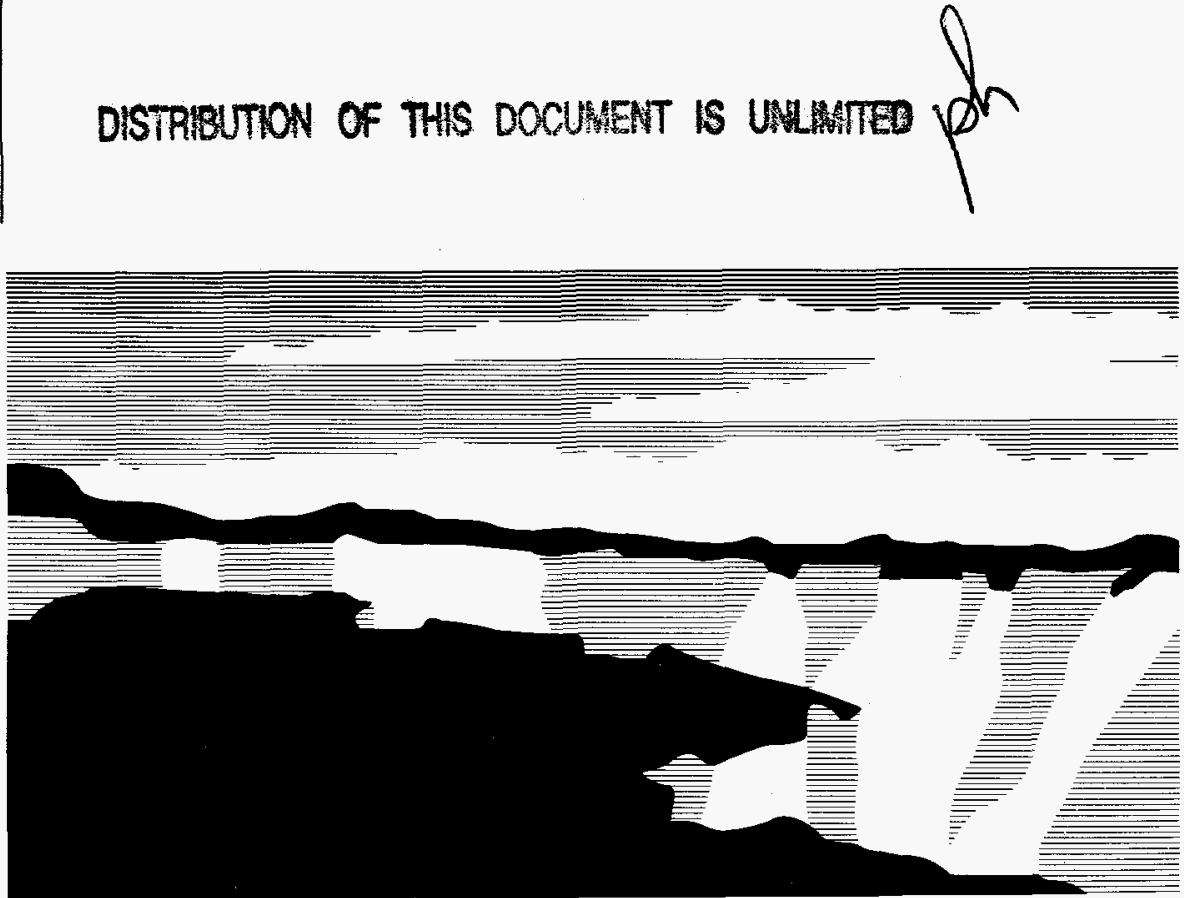

Los Alamos National Laboratory, an affirmative action/equal opportunity employer, is operated by the University of California for the U.S. Department of Energy under contract W-7405-ENG-36. By acceptance of this article, the publisher recognizes that the U.S. Government retains a nonexclusive, royalty-free license to publish or reproduce the published form of this contribution, or to allow others to do so, for U.S. Government purposes. The Los Alamos National Laboratory requests that the publisher identify this article as work performed under the auspices of the U.S. Department of Energy. 


\section{DISCLAIMER}

This report was prepared as an account of work sponsored by an agency of the United States Government. Neither the United States Government nor any agency thereof, nor any of their employees, make any warranty, express or implied, or assumes any legal liability or responsibility for the accuracy, completeness, or usefulness of any information, apparatus, product, or process disclosed, or represents that its use would not infringe privately owned rights. Reference herein to any specific commercial product, process, or service by trade name, trademark, manufacturer, or otherwise does not necessarily constitute or imply its endorsement, recommendation, or favoring by the United States Government or any agency thereof. The views and opinions of authors expressed herein do not necessarily state or reflect those of the United States Government or any agency thereof. 


\section{DISCLAIMER}

\section{Portions of this document may be illegible in electronic image products. Images are produced from the best available original document.}


 \\ Remote Monitoring of Volcanic Gases using Passive Fourier Transform Spectroscopy
}

\author{
Steven P. Love, Fraser Goff, Dale Counce and Stephen C. Schmidt \\ Space \& Remote Sensing Sciences (NIS-2) and Geology \& Geochemistry (EES-1) Groups \\ Los Alamos National Laboratory, MS C-323, Los Alamos, NM 87545 \\ splove@lanl.gov, fraser@lanl.gov, counce@lanl.gov, scs@lanl.gov \\ Claus Siebe and Hugo Delgado \\ Instituto de Geofísica, Universidad Nacional Autónoma de México, Coyoacán 04510, México, D.F., Mexico. \\ csiebe@tonatiuh.igeofcu.unam.mx, hugo@tonatiuh.igeofcu.unam.mx
}

Volcanic gases provide important insights on the internal workings of volcanoes and changes in their composition and total flux can warn of impending changes in a volcano's eruptive state. In addition, volcanoes are important contributors to the earth's atmosphere, and understanding this volcanic contribution is crucial for unraveling the effect of anthropogenic gases on the global climate. Studies of volcanic gases have long relied upon direct in situ sampling, which requires volcanologists to work on-site within a volcanic crater. Such work presents obvious dangers, and indeed many volcanologists have lost their lives pursuing volcanic gas studies. In recent years, spectroscopic techniques have increasingly been employed to obtain information on volcanic gases from greater distances and thus at reduced risk. These techniques have included UV correlation spectroscopy ("Cospec") for $\mathrm{SO}_{2}$ monitoring, the most widely-used technique, and infrared spectroscopy in a variety of configurations, both open- and closed-path (see Oppenheimer et $a l^{1}{ }^{1}$ for a recent review).

Though open-path IR spectroscopy of volcanic gases has been demonstrated at several volcanoes by various groups, it has typically required rather special circumstances - either fortuitously located high-temperature rocks or lava acting as an infrared source, or a combination of accessible topography and minimal volcanic hazard allowing installation of an artificial infrared source across the plume from the spectrometer. Such optimal conditions are not generally present at the most active and dangerously explosive volcanoes for which gas monitoring is most crucial. More recently, Francis et l. $^{2}$ have demonstrated good results using the sun as the IR source. This solar occultation technique is quite useful, but puts rather strong restrictions on the location of instrument and is thus best suited to more accessible volcanoes.

In order to maximize the flexibility and range of FTIR measurements at volcanoes, our work over the last few years has emphasized techniques which utilize the strong radiance contrast between the volcanic gas plume and the sky., These sky-background techniques yield high-quality infrared spectra in a truly passive manner, without artificial IR sources, from distances of many kilometers. With their great flexibility in instrument location, these methods are particularly useful for inaccessible and dangerously explosive volcanoes. In the long-wave IR region (LWIR, 8-12 $\mu \mathrm{m}$ ), gas spectra are obtained as emission spectra by viewing the warm plume against the colder backdrop of clear sky. In the mid- and short-wave IR regions (MWIR, SWIR, 2-5 $\mu \mathrm{m}$ ), high quality absorption spectra are obtained using sunlight scattered from clouds behind the gas plume.

We have successfully employed these techniques at several volcanoes, including the White Island and Ruapehu volcanoes in New Zealand, the Kilauea volcano on Hawaii, and Mt. Etna in Italy. But Popocatépetl $(5452 \mathrm{~m})$, the recently re-awakened volcano $70 \mathrm{~km}$ southeast of downtown Mexico City, has provided perhaps our best examples to date of the usefulness of these techniques. ${ }^{3,4}$

Popocatépetl has produced repeated devastating explosive eruptions in the past, in cycles of roughly 1000 to 3000 years, the most recent major episode occurring between 675 and $1095 \mathrm{AD}$. Its current activity, beginning in December 1994, temporarily displaced 75,000 people, and has continued to this writing, with frequent explosions sending ash plumes as high as $10 \mathrm{~km}$ above the summit. This level of activity makes remote FTIR particularly valuable, since any gas measurement technique requiring human presence near the summit is far too dangerous. 
In February, 1997 and again in Feb., 1998, we performed remote IR spectroscopy at Popocatépetl using a commercial FTIR manufactured by Midac, Inc. Figure 1 displays typical LWIR clear-sky spectra, showing $\mathrm{SO}_{2}$, numerous $\mathrm{H}_{2} \mathrm{O}$ lines, plume aerosol continuum emission, and, notably, $\mathrm{SiF}_{4}$. $\mathrm{SiF}_{4}$ had been previously detected at Italy's Vulcano and Etna volcanoes by Francis et al. ${ }^{5}$ who used FTIR and a hot IR source. In the emission geometry we can monitor $\mathrm{SiF}_{4}$ from much greater distances $(17.5 \mathrm{~km}$ is our current record, but greater distances are possible in good weather). One complication of remote emission spectroscopy is that absolute radiometric calibration becomes essential for quantitative measurements. This was performed approximately every hour using two blackbody sources consisting of insulated, temperature-controlled, grooved aluminum plates coated with a high infrared emissivity paint. MWIR spectra at Popocatépetl were obtained by viewing a high thin cloud layer in the general direction of the sun (within approximately $40^{\circ}$ ). Sunlight is strongly scattered toward the instrument by such clouds, providing an ideal bright background against which the plume can be viewed in absorption. The MWIR absorption spectra in Fig. 2 clearly show $\mathrm{SO}_{2}, \mathrm{HCl}$ and $\mathrm{HF}$, which can be monitored with time resolutions on the order of minutes, as shown in Fig. 2(c). In general, remote FTIR measurements are most useful for monitoring relative quantities of the various gases; spectra typically require tens of seconds to acquire, and knowledge of gas temperature is needed to determine absolute concentrations, making total gas flux measurement using the FTIR alone currently impractical. For this reason, we supplement the FTIR with UV Cospec measurements of the total $\mathrm{SO}_{2}$ flux, and combine the results to obtain fluxes for all the gases. The FTIR-derived ratios of the various gases are in good agreement with earlier (1994 to 1996) results obtained by more direct methods; ${ }^{4}$ (see Love et $a .^{3}$ for details).

One remarkable observation at Popocatépetl was a steady increase in $\mathrm{SiF}_{4} / \mathrm{SO}_{2}$ preceding an explosive steam and ash eruption, with an extremely high value of this ratio immediately afterwards. ${ }^{3}$ This trend, along with the total $\mathrm{SO}_{2}$ flux, is summarized in Fig. 3. Previous research demonstrates that $\mathrm{SiF}_{4}$, which is formed from the reaction of $\mathrm{HF}$ with silicates, increases with falling temperature and is not abundant at magmatic temperatures. ${ }^{6}$ Thus we have the surprising result that the gases underwent

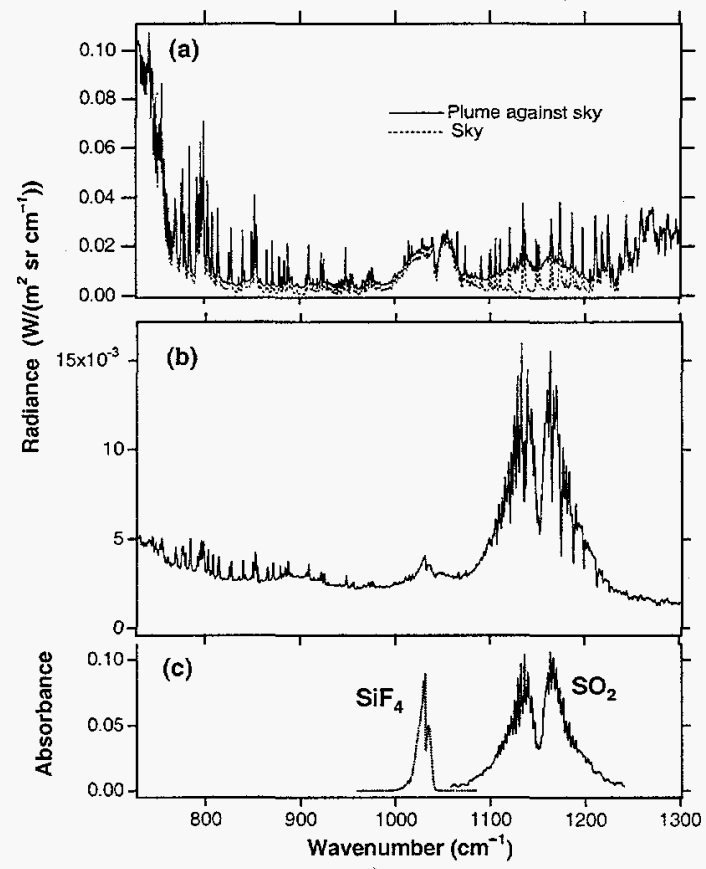

Figure 1. LWIR spectra of the Popocatépetl plume, obtained Feb 23, 1997 at a range of $4 \mathrm{~km}$. Spectral resolution is $1 \mathrm{~cm}^{-1}$. (a) Radiance spectra of the plume viewed against clear sky and of plume-free clear sky.

(b) Difference between plume and sky spectra.

(c) Laboratory $\mathrm{SiF}_{4}$ and $\mathrm{SO}_{2}$ spectra, for comparison.
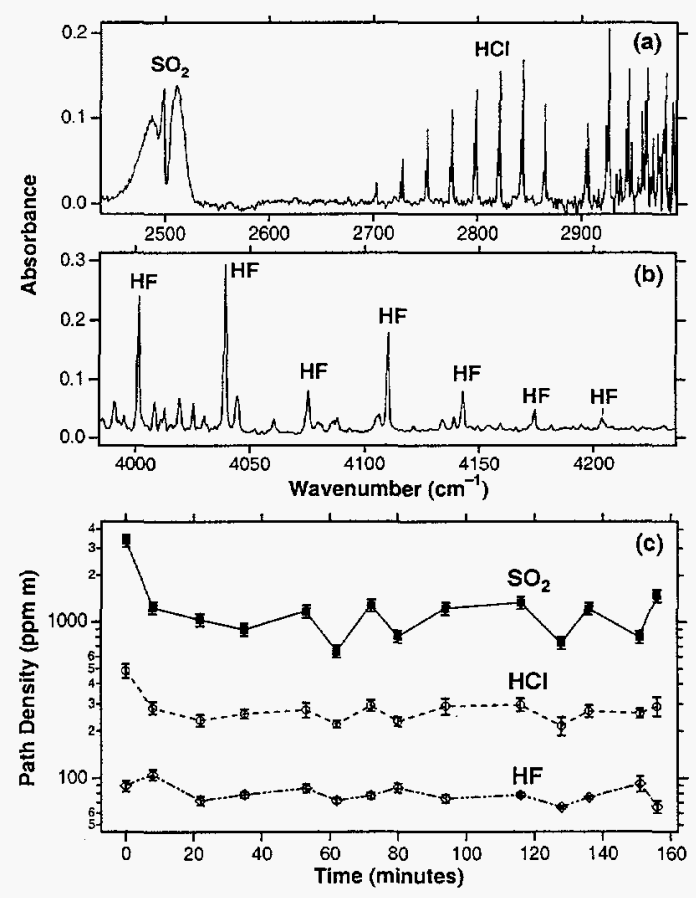

Figure 2. MWIR spectrum of the Popocatépetl plume, obtained Feb. 4, 1997, using cloud-scattered sunlight, showing (a) $\mathrm{HCl}$ and $\mathrm{SO}_{2}$ and (b) $\mathrm{HF}$. Spectral resolution is $1 \mathrm{~cm}^{-1}$. (c) Time dependence of the path densities of the three gases. 

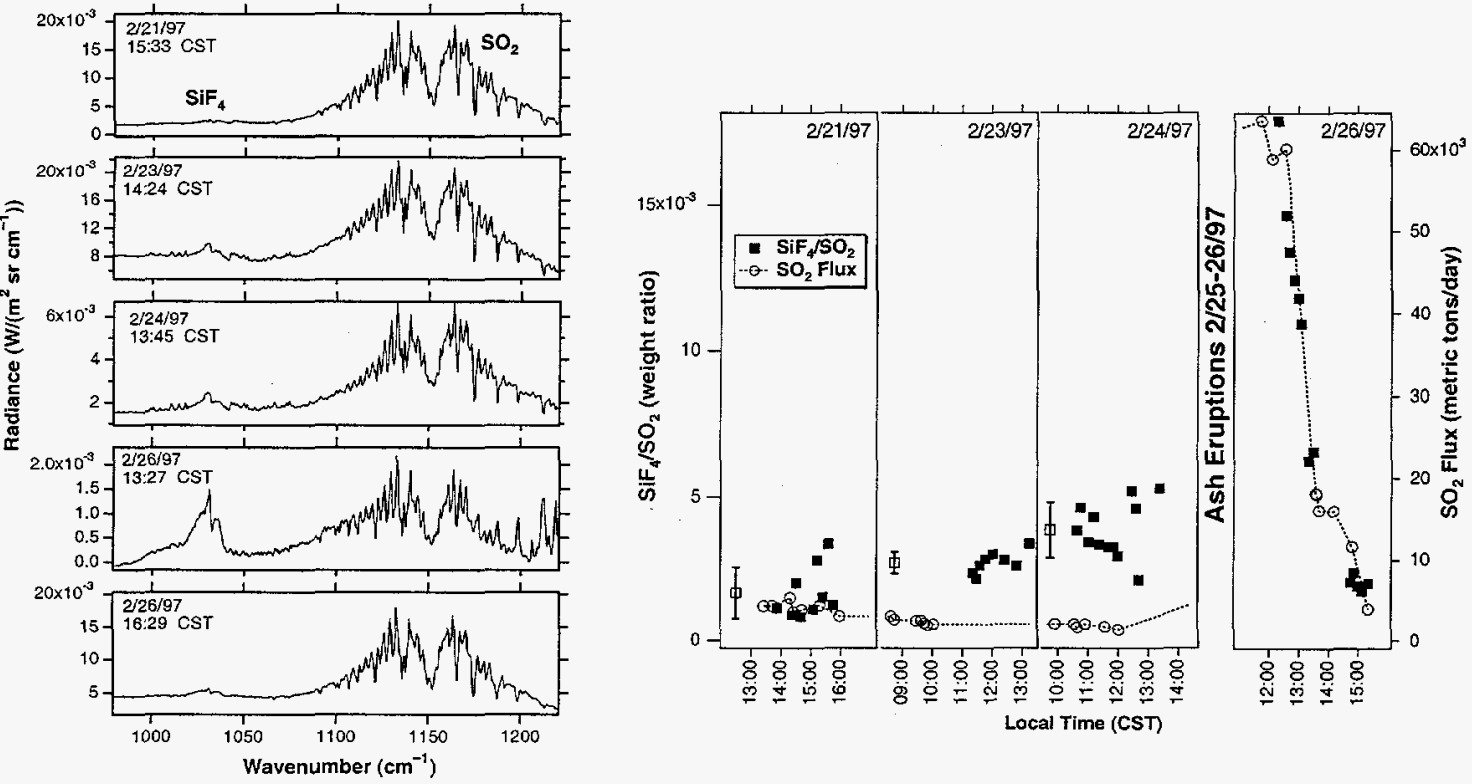

Figure 3. Time variation of $\mathrm{SiF}_{4} / \mathrm{SO}_{2}$ at Popocatépetl, Feb. 21-26, 1997. On the left are representative spectra (ranges 4 to $10 \mathrm{~km}$ ); Right side summarizes changes in the $\mathrm{SiF}_{4} / \mathrm{SO}_{2}$ ratio, along with total $\mathrm{SO}_{2}$ flux, over this period. Points with error bars indicate the mean and standard deviation for each day; note the daily increase leading up to the steam and ash eruptions of Feb. 2526.

cooling prior to the explosion. We speculate that this reflects an adiabatic expansion which occurred as a plug in the volcanic conduit began giving way prior to the explosion. As the plug weakened, releasing gas, pressure and temperature decreased, increasing $\mathrm{SiF}_{4} / \mathrm{SO}_{2}$. Eventually the plug failed catastrophically, producing the observed explosion, a large drop in temperature and pressure, and the observed large increase in $\mathrm{SiF}_{4} / \mathrm{SO}_{2}$. This spectral signature could serve as a warning of similar events, which occur frequently at Popocatépetl.

Our 1998 campaign at Popocatépetl ${ }^{7}$ yielded the additional surprise of occasional anomalously large bursts of $\mathrm{CO}_{2}$. Large enough to be detected easily by remote FTIR at a range of $7 \mathrm{~km}$, despite the obvious problem of interference from atmospheric $\mathrm{CO}_{2}$, these $\mathrm{CO}_{2}$ anomalies were also detected by airborne sampling, confirming the remote FTIR results.

Remote FTIR studies ideally complement other techniques available for gas monitoring, and are uniquely valuable at explosive volcanoes like Popocatépetl. FTIR permits quasi-continuous gas composition monitoring right up to an eruption, without unduly endangering the scientists involved. Future work should emphasize longer term, more continuous gas monitoring, and, ideally should combine remote FTIR with more direct techniques as safety permits. Such studies, combined with seismic and geodesic measurements, will permit more meaningful correlations between trends in gas composition with various types of eruptive activity.

\section{References}

1. C. Oppenheimer, P. Francis, M. Burton, A. J. H. Maciejewski, and L. Boardman, "Remote measurement of volcanic gases by Fourier transform infrared spectroscopy," Appl. Phys. B 67, 505-515 (1998).

2. P. Francis, M. R. Burton, and C. Oppenheimer, "Remote measurements of volcanic gas composition by solar occultation spectroscopy," Nature 396, 567-570 (1998).

3. S. P. Love, F. Goff, D. Counce, C. Siebe, and H. Delgado, "Passive infrared spectroscopy of the eruption plume at Popocatépetl volcano, Mexico," Nature 396, 563-567 (1998).

4. F. Goff, et al., "Geochemical Surveillance of magmatic volatiles at Popocatépetl Volcano, Mexico," Geol. Soc. Am. Bull 110, 695-710 (1998).

5. P. Francis, C. Chaffin, A. Maciejewski, and C. Oppenheimer, "Remote determination of $\mathrm{SiF}_{4}$ in volcanic plumes: A new tool for volcano monitoring," Geophys. Res. Lett. 23, 249-252 (1996).

6. R. B. Symonds and M. H. Reed, Am. J. Sci. 293, 758-864 (1993).

7. S. P. Love, et al, "Applicability of passive open-path IR spectroscopy for volcanic $\mathrm{CO}_{2}$ monitoring," EOS Trans. Am. Geophys. Union 79, F927 (1998 Fall Meeting) (1998).

8. H. Delgado, "CO $\mathrm{CO}_{2}$ flux measurements at Popocatépetl volcano: II. Magnitude of emissions and significance," EOS Trans. Am. Geophys. Union 79, F926 (1998 Fall Meeting) (1998). 